\title{
Economic Analysis of Law as Implementation of Petrazhycki's Project for Externalist Theory of Legal Policy
}

\section{目 Gadis Gadzhiev'}

Justice, the Constitutional Court of the Russian Federation; Professor, National Research University Higher School of Economics (Saint Petersburg Campus). Address: 1 Senatskaya Square, Saint Petersburg 190000, Russian Federation. E-mail: gadg@ksrf.ru



Professor Leon (Lev) Petrazycki contributed significantly to the methodology of law and economics and made Russian legal science famous in Germany with the publication Die Lehre von Eienkommen in 1893 and 1895. The book developed the idea that the influence of legal norms should be evaluated not only from the private view but from the point of national economy. Professor Petrazycki and his students Pitirim Sorokin and George Guins may be ranked among the founders of the economic analysis of law established in $20^{\text {th }}$ century, which was shown earlier in the monograph Pravo i ekonomika (metodologiya) by the author of the paper. The idea of externalism is based on the principle that social and economic factors, i.e. extra scientific make a decisive influence on the development of science. Hence, in studying the history of science, the major task is reconstructing social and cultural conditions (social service) promoting to the development of ideas and theories. The opposite, internalist, approach promotes the idea that science develops only due to inner scientific factors - on the basis of objective logic and of arising and solving economic problems, thanks to the evolution of scholar traditions, create new concepts, solve problems etc. Law has developed two types of argumentation externalist and internalist. Legal positivism calls for the strict adherence to the norms of positive law and excludes other arguments sociological, economic, moral, historical ones in resolving legal disputes. This is the internalist approach showing the separation of legal space from others (economic, moral etc.). In this regard, the politics of law is something external in terms of law, and the area is intended for politicians. The external type of argumentation allows avoiding extremes and formalism for legal concept. This area of legal science is characterized with open ways of argumentation - sociological and statistical facts, economic rationale, moral arguments. A high idealistic dream of external jurisprudence is in the following: it is necessary to achieve three criteria for legal decisions: legality, efficiency, fairness.
\end{abstract}

\section{O-1国 Keywords}

legal science, private law, economic analysis, internalistic approach, externalism, efficiency.

Citation: Gadzhiev G.A. (2017) Economic Analysis of Law as Implementation of Petrazhycki's Project for Externalist Theory of Legal Policy. Pravo. Zhurnal Vysshey shkoly ekonomiki, no 4, pp. 31-45 (in English)

JEL: K10

DOI: 10.17323/2072-8166.2017.4.31.45

\footnotetext{
${ }^{1}$ The article was edited and translated by Prof. Edoardo Fittipaldi, to whom I am extremely grateful.
} 


\section{Introduction}

In order to understand the phenomenon of Leon Petrazhycki it is necessary to recall the history of the development of what is called legal science or legal theory in the Russian Empire and especially the role played in this context by the study of Roman law ${ }^{2}$. The history of Russian law is closely related to that of Byzantine law, but beginning in the 18th century, it began to be linked to Roman law as well. The first two professors who came to Moscow teach law at Russia's first university were German professors of Roman law.

During the 19th century, an important role in the development of legal science in Russia was played first (in 1829) by training some Russian students at the University of Berlin and then by the establishment (in 1884-1885) of a Russian Seminar for Roman Law (Russisches Seminar für römisches Recht)-still in Berlin ${ }^{3}$. The University of Berlin was chosen because of the dynastic ties between the Romanovs and the Prussian monarchs. The establishment of the Russian Seminar for Roman Law in Berlin for the training of Russian Romanists produced excellent results. Between 1887 and 1896, under the guidance of Heinrich Dernburg and Alfred Pernice, such prominent Russian specialists in private law as David Grimm, Aleksej Guljaev, Leon Petrazhycki, Iosif Pokrovskij, Evgenij Passek, and many others were trained. This was the starting point for Russia's elite tier of legal theorists; and among them, first and foremost, we find Leon Petrazhycki, who gained fame in Europe through his two-volume Theory of Incomes published in Germany in 1893 and 1895.

Petrazhycki's Theory of Incomes became the center of attention for Russian legal science even before he had published an improved Russian version of some of its parts (especially the appendix to the second volume under the title Policy of Private Law and Political Economy, in German).

The works of Russian scholars like Pyotr Gutovic and especially Sergei Muromtcev, who advocated a sociological approach to the development of private law ${ }^{4}$, paved the way for Petrazhycki's contributions. He was also definitely influenced by Anton Menger (1886), who held that, alongside the doctrine of private law, a theory of legislativ-politische Jurisprudenz should be developed and that it should focus on issues de lege ferenda.

In 1898 at the University of Kazan Gabrièl Shershenevic published an essay entitled The Tasks and Methods of the Theory of Private Law in which he considered Petrazhycki's Good Faith in Private Law (1897, in Russian) and his Introduction to the Theory of Legal Policy (2010) and stated that Petrazhycki was the most brilliant exponent of the latest trends in private law.

According to Shershenevic, the most important ideas contained in those works were as follows:

1. alongside the dogma of private law, Petrazhycki proposed creation of a new legal science, namely, the science of the policy of private law which would investigate how private law should be conceived;

2. this new science would not go beyond the historically established boundaries of private law, and so would not address social issues, as these latter come within the domain of public law;

${ }^{2}$ Avenarius $M$. Fremde Traditionen des römischen Rechts. Einfluß, Wahrnehmung und Argument des 'rimskoe pravo' im russischen Zarenreich des 19. Jahrhunderts. Göttingen, 2014. P. 776.

3 See: Kolbinger F. Im Schleppseil Europas? Das russische Seminar für römisches Recht bei der juristischen Fakultät der Universität Berlin in den Jahren 1887-1896. Frankfurt am Main, 2004.

${ }^{4}$ Muromtsev S.A. Opredelenie i osnovnoe razdelenie prava [Definition and Main Division of Law]. Moscow, 1879. 
3. the bedrock principle upon which the whole policy of law should rest is benevolence or love;

4. and, most importantly, the influence of legal norms should be evaluated from the standpoint of the overall national economy, and not from the standpoint of the private interests involved. ${ }^{5}$

The first author to call the attention to the similarity between Petrazhycki's ideas and the methodological foundations of the economic analysis of law-sometimes referred to as law and economics-was Tomasz Giaro, who in 2009 had published a series of articles on this subject both in Polish and in Russian ${ }^{6}$. During that same year, an article on that subject by Edoardo Fittipaldi also appeared ${ }^{7}$. For more in support of the idea that Petrazhycki-as well as his pupils Pitirim Sorokin and Georgij Guins - can be regarded as the first herald of the economic analysis of law. In the Russian literature on these topics Artyom Karapetov ${ }^{8}$ also mentions Petrazhycki in the context of economic analysis of law.

I would claim that the English literature on the origins of the economic analysis of law can be justifiably criticized for overlooking the fact that Petrazhycki's policy of law (politika prava) anticipated many theoretical concepts of the former. I agree with Tomasz Giaro that Petrazhycki was a forerunner of the economic analysis of law, and I shall build a case of my own demonstrating that Petrazhycki actually did create a methodology for an economic analysis of law. To this end I shall make use of legal-philosophical categories, and particularly those of internalism and externalism applied to the realm of legal phenomena.

In the history of legal science, just as in the history of economic theory, one can discern analogous stages as each discipline strives to become autonomous. This striving for separation-justified by invoking the distinctiveness of both the subject and the methods applied to attaining theoretical knowledge-is both necessary and useful. For legal science, the striving for autonomy of the legal realm may be explained, inter alia, by an urge no longer to be a theoretical ancillary to theology. However, as soon as a higher level of understanding of reality is reached, the autonomist pictures of both the legal and the economic world appear to be insufficient. Figuratively speaking, such an evolution can be compared to the transition from black and white to color photography, and then to the stereoscopic representation of reality, when a "third dimension", namely space, is incorporated. All in all, economic theory has evolved along the same epistemological path as legal theory. During the 18th and 19th centuries, economic theory conceived of "firms" and "economic activity" as completely autonomous phenomenaexisting independently of the other aspects of social life, such as law, ethics, and culture in a broad sense.

In the case of legal science, internalism amounts basically to a particular ontological approach to legal categories, understood as having a reality that is self-supporting, or independent of those addressed by other branches of the humanities. Legal science-and especially what is called legal doctrine-has elaborated a relatively uncomplicated method for tackling legal problems that are themselves sometimes extremely complicated. Jurists are accustomed to ignoring Ulpian's admonition that, when considering legal cases, they are concerned with a

${ }^{5}$ It should be recalled that Shershenevic was one of the first jurists to investigate private law by using the methods of economic analysis. See: Shershenevic G.F. Avtorskoe pravo na literaturnye proizvedeniya [The Copyright on Literature Works]. Kazan,1891. 321 p.

${ }^{6}$ Giaro T. Leon Petrazhycki - osnovopolozhnik ekonomicjeskogo analiza prava [Founder of Economic Analyzis of Law] // Ekonomika. Predprinimatelstvo. Okruzhaiuschaya sreda, 2009, no 2.

7 Fittipaldi E. Bonae fidei possessor fructus consumptos suos facti. Tentative Answers to One Question Left Open by Leon Petrazycki's Economic Analysis of Law // Societas/Communitas, 2009, no 7, p. 15-36.

${ }^{8}$ Karapetov A.G. Ekonomichesky analiz prava [Economic Analyzis of Law]. Moscow, 2016. 528 p. 
"true philosophy, not a semblance of it" (cf. Dig. 1.1.1.1). However, often they do this unwittingly. As Spektorskij ironically observed, they practise philosophy much as Molière's bourgeois gentilhomme spoke prose for more than forty years without realizing it:

No matter how trivial a minor everyday case of common legal science is, it is still built on premises derived from philosophy and, moreover, of the greatest depth. In the business of the courts there are considerations of ethics and metaphysics, and even of the theory of knowledge-in short, the whole of philosophy ${ }^{9}$

An internalistic approach to legal science rejects such an approach for solving legal problems and affirms that the legal science-thanks to centuries of legal doctrines-has constructed its own legal metaphysics, a metaphysics that makes it possible to solve legal problems from within, that is, by using of arguments with a purely juristic origin. Internalistic legal sciences are popular in continental Europe. Grechenig and Gelter are inclined to see a connection between this popularity and the fact that "the German attitude was profoundly anti-utilitarian and thus hostile to law and economics"10.

In my opinion, the fixation on the idea that economic and legal realms are autonomous should now be abandoned. To this end, it is necessary to correct some simplistic and extremely reductionist ideas and to create a more complex picture of reality-a multicolor and stereoscopic one-which portrays economic relations based on the idea that law, economics, and ethics are an indivisible trinity.

This cognitive strategy is a fundamental idea in the study of law and economics or the economic analysis of law. There is nothing destructive or revolutionary in it. Neither legal dogma nor economic theory-each of which has created its own picture of reality of by developing its own theoretical methods-have necessarily to accept compromises with it. However, each of them can benefit from a combination of their respective methods. This would mean that a new subject for a new science-i.e., law and economics-would emerge along with new theoretical methods.

\section{On Petrazhycki's externalism in the domain of policy of law}

Petrazhycki was a confirmed externalist in developing methodology of his policy of private law. However, he handled "the achievements of juridical genius"11, quite carefully, and these were "the settled juridical method-a method that has been predominant for entire millennia".

According to him, legal policy, as a science or theory concerned with how law should be conceived with achievement of the ideal of benevolence or love as its goal is essentially different from legal dogma or doctrine understood as a science studying positive law. The object and the method of those two sciences do not coincide. Each of them has its own tasks and domain of investigation. Thus, each of them is to develop its own autonomous method according to its own object. Now, the epistemological methodology for legal policy adopted by Petrazhycki is strikingly similar to the epistemological postulates of the «law and economics» field. On the one hand, according to him, the juristic method used by the dogma of private law aims P. 63.

${ }^{9}$ Spektorskij E.V. Jurisprudentcia i filosophia [Jurisprudence and Philosophy // Juridicheski vestnik. 1913.

${ }_{10}$ Grechenig K., Gelter M. The Transatlantic Divergence in Legal Thought: American Law and Economics vs. German Doctrinalism // Hastings International and Comparative Law Review, 2008, no 1, p. 296.

${ }^{11}$ Petrazhycki L. Teoria i politica prava. Izbrannye trudy [Theory and Policy of Law. Selected Works]. Moscow, 2010. P. 29. 
at disclosing the true meaning of legal provisions (interpretation), and at extracting general principles and concepts from specific provisions by using the general method of abstraction, and then at deriving from those general principles and concepts new norms for private law or specific rulings in concrete legal disputes ${ }^{12}$. As he argued in Modern Slogans in Jurisprudence, if we were to leave the firm ground of positive law and "freely" relate to the sources of law, then, instead of a firm and solid foundation for the people's legal life-that which legal dogma should be-a tower of Babel would arise and inevitably be doomed to fall. As far as the epistemology of legal dogma was concerned, he praised Puchta and Windscheid, and strived for the purification of the method of legal dogma from extraneous contaminants, and he placed great emphasis on the purity of its method. ${ }^{13}$ But Petrazhycki could not help observing that "...usually jurists try to prove that black is white" 14 , that is to say, that they try to prove that their interpretations are in accordance with the meaning of the legal sources and do so even when the error of their contrivances and the sophistry (sofizm) involved in them would be obvious to any impartial observer. In this regard, he adds that "...this phenomenon is contrary to the necessities of ethics and aesthetics, and to the essence of science, which is to uproot lies and strive for truth"15.

Needless to say, according to Petrazhycki, this holds not only for legal dogma but also for legal policy, which according to him is also determined ethically. But what is the content of the methodology of legal policy? Having conceded that the novelty of legal policy is quite a relative one, he writes that it should be based, on the one hand, on materials that in his time were customarily collected and presented under the rubric of philosophy of law or compendium of law" (Filosofia i enciklopedia prava), and, on the other hand, on materials to be found in the history of law.

However, he also observes that many domains of legal policy should be studied using the methods and theories developed by political economy, which he regarded as the "most satisfactory of the social sciences"16. Long before the works of John Commons, Aaron Director and subsequently Ronald Coase, Guido Calabresi, Richard Posner, Gary Becker, Thomas Ulen etc., Petrazhycki wrote that the methods devised by the study of economics for the investigation of law show great promise and are extremely useful for jurisprudence. He expressly criticizes the professors of private law of his time for their unwillingness and inability to make use of the results and methods created and employed by economics.

One can but wonder that English-speaking scholars did not notice the similarity between the epistemological, ontological, and axiological foundations of Petrazhycki's legal policy and the economic analysis of law.

Where do I see a similarity between the axiological foundations of contemporary economic analysis of law and Petrazhycki's policy of law? As is well known, he held that the object of the policy of private law is the legal mechanisms making up decentralized economic systems ${ }^{17}$.

12 Petrazhycki L. Teoria gosudarstva i prava [Theory of State and Law]. Saint Petersburg, 1909.

${ }^{13}$ Petrazhycki L. Modnye lozungi jurisprudentcii [Modern Slogans in Jurisprudence] / Petrazhytcki L. Prava dobrosovestnogo vladeltza na dochody s tochek zrenia dogmy i politiki grazhdanskogo prava [Rights of Bona Fide Owner for Income from the View of Civil Law Dogma and Policy]. Moscow, 2002. P. 376. Hans Kelsen would use these very same terms many years later. Some argue that Petrażycki's methodological purity as applied to legal dogma may be regarded as even purer than Kelsen's. See: Fittipaldi E. Op. cit. P. 35.

14 Petrazhycki L. Theory and Policy of Law... P. 31

15 Ibid.

16 Ibid. P. 459.

17 Ibid. P. 42. 
Decentralized systems emerge because of equality before the law, the economic independence of economic decision-making entities, and the absence of a unified plan of economic action.

Here is how Petrazhycki characterizes the main task of the policy of private law relative to policy of law in general:

Its specific and immediate task is of an economic nature, namely, the improvement of the decentralized systems of legal organization of national economies in terms of achieving the best possible results in this domain, and thus both from the standpoint of the magnitude of the national wealth (the amount of means available for the satisfaction of needs) and from the standpoint of distribution.

But, since the policy of private law is subordinated to legal policy in general, the aforementioned task should be subordinated to the general ideal of legal policy. Therefore, one should constantly consider whether the expected economic result in the domain of production or in the domain of distribution corresponds to the general ideal of policy of law and culture. Further, the norms of private law have an ethical and cultural relevance not only because of the economic results they produce but also indirectly, specifically because they elicit one motivation over another, etc. Therefore, it is clear that the task of the legal-political critique of a certain legislative project, to take one example, consists, first, of the assessment of its economic impact, and, second, of its, so to speak, second-level ethical evaluation. ${ }^{18}$

This means that the evaluation of the regulatory impact of given legal norms is to be made by means of the method of legal policy and should consist first of all of the assessment of their "economic impact", that is to say, their economic efficiency. In fact, Petrazhycki writes that:

if, for example, from the standpoint of the ideal [of benevolence or love], we regard as sufficiently justified the general principles according to which an increase in the national wealth or a more uniform distribution thereof is a desirable phenomenon, then, when studying special issues we can adopt those principles as solid starting points [dannye]. For example, in a concrete case it is sufficient to point out that a certain legal norm would be useful from the standpoint of successful production or from the standpoint of a more egalitarian distribution without always reverting to the essence and the purpose of civilization and law [respectively $]^{19}$.

Thus, when it comes to his policy of private law, we can conclude that its axiological foundation amounts to the choice of decentralized production, the absence of a single plan, the economic freedom of producers, freedom of contract, and legally protected private property.

\section{Economic Analysis of Law as the Implementation of Petrazhycki's Program for Policy of Law}

Let us now compare these ideas with the axiological basis of the economic analysis of law. That discipline analyses human behavior within the economic sphere. The economists of that school borrow their basic methods for the investigation of the legal norms regulating economic relations from the theory of rational choice. The point of departure for this theory is the assumption that, in a situation with limited resources, human beings are utility maximizers. Economic analysis of law investigates legal norms as tools for enabling the removal of so-called market failures.

When addressing the essence of the methodological approaches making up the content of the theory of rational choice, these economists unanimously agree that its basis is methodological individualism, according to which the fundamental object of analysis-much as for Petrazhycki-is human behavior. On that basis these economists assume the existence of multiple

\footnotetext{
18 Ibid. P. 43.

19 Ibid.
} 
markets (e.g., the marital market) which had not been investigated previously. Legal norms are regarded as containing or setting specific prices for each variant of human behavior ${ }^{20}$.

In the 20th century Armen Alchian and Ronald Coase attempted to invert the ranking of values in the domain of legal norms by putting economic efficiency ahead of justice.

It is well known that Coase formulated one of the most fundamental principles of the law and economics movement: When it is possible to sell and buy enforceable rights, a rearrangement of them through transactions in the market of their initial allocation will always take place, if it will lead to the ascription of those rights to those who value them the most ${ }^{21}$. But Coase made a very important addition to his theorem, stating that it holds only in the absence of transaction costs. When transaction costs are high, transfers of rights will rarely take place. Coase's example is that of a factory emitting smoke into the neighboring private space. Those affected by the smoke may be quite numerous, and if the owner of the factory were to negotiate the purchase of the right to cause damage to each of his neighbors, he would find that the transaction costs are exorbitant. They might turn out to be so high as to cause the owner to agree to levels of pollution that restrict maximum efficiency, or even to prevent any transaction whatsoever from being entered into with the owners of the adjoining private spaces.

This inevitably leads to the conclusion that both the law-making bodies and the courts should be guided not only by legal logic but also by economic logic when making decisions, and, above all, by considerations of economic efficiency, which Petrazhycki (and Shershenevic) called the "the viewpoint of national economy" (i.e., the idea that the influence of legal norms should be evaluated within the policy of law from the standpoint of the national economy, rather than from that of private economic interests).

If the participants in a given transaction do not foresee the consequences of various kinds of risks, if there is no legal provision for such a case, and if the costs of negotiation-or transaction costs-are high, the problem of the distribution of risks must necessarily be addressed by the courts. Is there an economic normativity - that is, a set of imperatives-that issues from economic efficiency rather than a legal normativity? Yes, there is ${ }^{22}$. Courts should allocate the risks - and the losses possibly connected with them-among the parties in the transaction in a manner that makes contractual relations and the future behavior of entrepreneurs efficient from the standpoint of society as a whole-i.e., efficient from the standpoint of the national economy.

Actually, this is the very starting point of any economic analysis of law: the result of a creative normative decision must be a rule according to which the losses should be borne by the party in the transaction that is able to bear the risk of losses with less costs from the standpoint of the national economy. As we know, as early as 1924 (and long before the American economic analysis of law was developed), John Commons wrote "transactions have become the meeting place of economics, physics, psychology, ethics, jurisprudence and politics"23.

This is what Commons wrote in the first chapter of his Legal Foundations of Capitalism:

Since transactions are the economic units, and working rules are the principles on which the Supreme Court of the United States has been working over its theories of property, sovereignty and value, and

${ }^{20}$ Becker G. Economic Approach to Human Behavior. Chicago, 1978. P. 230.

${ }^{21}$ Coase R. The Problem of Social Cost // Journal of Law and Economics, 1960, no 3, p. 1-44.

22 Schäfer H. Allokationseffizienz als Grundprinzip des Zivilrechts / C. Ott \& H. Schäfer (eds.) Allokationseffizienz in der Rechtsordnung. Beiträge zum Travemünder Symposium zur ökonomischen Analyse des Zivilrechts 1988. Berlin, 1989.

${ }^{23}$ Commons J. Legal Foundations of Capitalism. New York, 1924. P. 394. 
since that court occupies the unique position of the first authoritative faculty of political economy in the world's history, we shall begin with the court's theory of property, liberty and value. For it is mainly upon that theory that modern business is conducted and that American legislatures, executives and inferior courts are held in conformity to the Constitution of the United States, which, as latterly interpreted by the Supreme Court, prohibits the taking of property, liberty or value without due process of law or equal protection of the laws ${ }^{24}$.

A court is like a third party in a transaction and, when arriving at a decision, it does not act based on mere whims or eccentricities. Commons held that it is guided by an ideal of supreme justice, which coincides with social economic efficiency. The most important decisions of the US Supreme Court often adopted unconsciously, or intuitively, by judges who were thinking in an economic way. Alongside the purely legal arguments, as well as conscious economic and ethical ones - which may be permissible as well according to a given legal order- it is possible to detect the working of unconscious, or intuitive, thinking by judges. One of the first authors to call the attention to this phenomenon was precisely the founder of institutional economics, John Commons. In his Legal Foundations of Capitalism he wrote about the crucial role played by judicial creativity in the development of the US economy. He demonstrates that it would be no exaggeration to say that the success of the American capitalism can be explained to a large extent by the fact that the Supreme Court adopted important decisions having major economic consequences. The sum of those decisions makes up a legal infrastructure that has fueled rapid economic development. Nothing favored the economic development of the US as much as the economically rational judicial decisions of the Supreme Court. This is probably why James Buchanan ${ }^{25}$ said, as early as in the second half of the 20 th century, that those wise judicial decisions, along with the laws, constitute so-called social capital, because of which the United States won out in the world contest for economic supremacy. The Supreme Court became a force that creates important economic rules which turn out to be the foundation of business. However, institutional economics investigates not only the Supreme Court itself as an institution creating norms, but also judicial precedents in general.

Of course, one cannot help associating these well-known statements with the Petrażyckian idea (an idea that he expressed many times and that he considered very important) "of "the instinctual political economy' [instinktivnaja političeskaja èkonomija] of Roman jurists, i.e., ... the unconscious economic efficiency [dejatel'nost'] of Roman law"26

Petrazhycki points to the unconscious economic wisdom (mudrost') of the institutions of Roman private law and holds that the study of that wisdom may transform that unconscious economic element of Roman law into a series of conscious thoughts.

He addresses the idea of the unconscious economic wisdom of Roman law in several writings including his critique of the provisions of the first draft of the German BGB. An example is what he writes about the way Roman law regulated the relationship between debtor and creditor with regard to loans. He writes ${ }^{27}$ that a deadline for returning the money loaned is usually agreed upon-e.g., a month, a year, etc. The debtor hopes to be able to secure the necessary sum of money by that deadline. The creditor assumes that when that same deadline arrives he will need that sum of money. But it often happens that, when the deadline expires, the creditor has no specific need of the money - and is not even interested in having his legal claim immediately

\footnotetext{
24 Ibid. P. 7.

${ }^{25}$ Buchanan J. The Limits of Liberty: Between Anarchy and Leviathan. Indianapolis, 2000.

${ }^{26}$ Petrazhycki L. Theory and Policy of Law... P. 47; idem. Rights of Bona Fide Owner... P. 270.

27 Idem. Theory and Policy of Law...P. 126.
} 
satisfied-whereas the debtor may have to struggle to repay it. According to Petrazhycki, there is no doubt that creditors often have a lenient attitude about the immediate payment of debts, and this fact has a beneficial impact both morally and an economically. How many families and productive companies would have been ruined, if creditors had never paid attention to their debtors' interests and had always deemed it necessary to obtain an immediate payment!

If a given economic good - e.g., the object of an obligation-has more value for the economic organization of the debtor than for that of the creditor, its temporary stay in the economic organization of the debtor brings her more utility than the utility the creditor would gain by means of its immediate transfer to his own economic organization. Such considerations from the viewpoint of overall social economic efficiency Petrazhycki called theorems (teoremy).

The more the creditor is interested in an immediate payment-i.e., the greater the subjective value that good has for her at a given time-the smaller the probability that she will postpone claiming that good to a later time. On the other hand, the utility of the postponement of the request to a later time and of not pressing the debtor increases along with the importance to the debtor of that behavior on the part of the creditor, hence the greater the utility the debtor gains from the postponement, the greater the damage averted by postponing payment. When economic goods are allocated where they satisfy the most intensive needs, national prosperity increases or its decrease is prevented. Based on these considerations, Petrazhycki argued against the rule dies interpellat pro homine (inserted in the project of the BGB) and argued for the requirement of the interpellatio as a more efficient economic solution-namely, the solution that was unconsciously arrived at by Roman jurists.

The idea of evaluating legal norms or judicial rulings "from the standpoint of the national economy" was used by him also to formulate a theory of economic crises. Owing to space limitations I will not address this issue. I shall confine myself to recalling that Petrazhycki worked several years on this problem, and that in 1911 he published Stocks, Speculation, and a Theory of Economic Crises. The author's main idea is that, in our age of economic crises, of dependence of productive companies on the use of credit, legal institutions should strive in a particularly careful way to preserve the integrity of the entrepreneurial structures. There is clearly an abundance of norms in contemporary corporate laws aimed at preserving the integrity of the asset base of a corporation. He wrote that jurists should pay more attention to the economic impact of the institutions of private law.

Sometimes legislators confine themselves to codifying independently existing economic systems which came into being historically and which are part of economic normativity. This is why, for example, the legislators of various countries and of various historical ages were influenced by the prevailing economic system and of the need for a rational use of limited economic resources, such as land, when they designed the rules of inheritance law. This is why, as early as the beginning of the Middle Ages, first customary law and then statutory law arranged the inheritance of land so as to avoid excessive fragmentation (so-called land parcelization). And this is why estates passed by inheritance only to the oldest son while the other sons where left to join the church or the military.

Basically, many conclusions arrived at by modern law and economic studies based on the Coase theorem were already formulated by Leon Petrazhycki.

When the former socialist countries faced the problem of finding a way to privatize state property, the Coase theorem provided an answer to the fundamental question of to whom and how state property should be transferred. According to the Coase theorem, the circumstances that are of crucial importance for jurists when it comes to regulating the transfer of state property to private hands are not very important from an economic standpoint, provided that legal 
conditions are created for an optimal-as regards allocative efficiency-selection process for owners that is, for example, free from abuse of insider information and shows due respect for the principle of equality, etc. To be sure, the history of voucher privatization of state property in Russia (1992-1994) confirmed the Coase theorem only partially because the citizens holding the vouchers sold them immediately for a pittance to those who had the capital to buy them, and these subsequent owners were not always the allocatively efficient owners (speculators hardly qualify as allocatively efficient owners).

Coase proposed a completely new normative source for judicial decision-making. In addition to the traditional sources of law-that is, primary or secondary legislation (in the British technical sense of those terms) and judicial precedents from which the courts commonly extract the norms necessary to support their juristic syllogisms-Coase proposed economic efficiency as a completely new source of norms that the courts should take into account:

when market transactions are so costly as to make it difficult to change the arrangement of rights established by the law...the courts directly influence economic activity. It would therefore seem desirable that the courts should understand the economic consequences of their decisions and should, insofar as this is possible without creating too much uncertainty about the legal position itself, take these consequences into account when making their decisions. Even when it is possible to change the legal delimitation of rights through market transactions, it is obviously desirable to reduce the need for such transactions and thus reduce the employment of resources in carrying them out. ${ }^{28}$

The whole structure of traditional legal science was shaken by Coase's proposal. No one had previously dealt such a serious blow to juristic thinking. However, one should bear in mind Coase's caution where he adds the qualification that his advice should be followed insofar as that is possible without creating too much legal uncertainty. This qualification testifies of his extensive knowledge not only of economics but also of law, as at the top of his value pyramid he put the principle of the rule of law, one aspect of which is legal certainty. Law must also be certain in the sense that the courts' decisions should be predictable, and that is possible when the decisions of the courts are restricted either by a system of legal provisions adopted by the legislature and the government and/or by a system of judicial precedents.

Oddly enough, economic theory and law did not come into conflict because of an economist like Ronald Coase, but instead because of a jurist, Richard Posner, who was first a professor at the Chicago Law School and then judge of the US Court of Appeals for the Seventh Circuit. It was Posner who proposed the concept of economic efficiency as a legal norm, thus prompting the debate with Ronald Dworkin ${ }^{29}$. The core of Posner's proposal can be summarized as follows.

When transaction costs are low and property rights are specified and can be transferred, the legal system does not affect efficiency because the various parties can always reach an efficient solution by negotiating. Where costs are high, the rules should be made in such a way that incentives are created for reaching an efficient outcome without negotiations and its attendant costs. It follows that the rules of common law should be regarded as a set of quasi-contracts; that is, they should mimic the contractual decisions the parties would adopt if the transaction costs were negligible.

Posner's position also led to a fierce debate on whether economic efficiency is a legal value. He holds, just as Commons does, that in arriving at decisions on economic issues the Ameri-

${ }^{28}$ Coase R. Op. cit. P. 90.

${ }_{29}$ Posner R. Utilitarianism, Economics, and Legal Theory // The Journal of Legal Studies, 1979, no 1, pp. 103-140; idem. The Ethical and Political Basis of the Efficiency Norm in Common Law Adjudication // Hofstra Law Review, 1980, no 8, pp. 487- 507; Dworkin R. Is Wealth a Value? // The Journal of Legal Studies, 1980, no 9, pp. 191-226; Fittipaldi E. Op. cit. P. 36. 
can courts - within a common law system based on judicial precedents-were functioning as virtual economists and that they were often guided not by precedents, but by economic norms such as efficiency rather than justice. In response to the critiques from legal theorists-most prominently, Ronald Dworkin-Posner writes:

"Justice" ... [s] ometimes ... means efficiency. We shall see, among other examples, that when people describe as unjust convicting a person without a trial, taking property without just compensation, or failing to make a negligent driver answer in damages to the victim of his negligence, this means nothing more pretentious than that the conduct wastes resources.... Even the principle of unjust enrichment can be derived from the concept of efficiency.... And with little reflection, it will come as no surprise that in a world of scarce resources waste should be regarded as immoral ${ }^{30}$

Now it does not seem to me an exaggeration to state that the following three Petrazhyckian statements-and especially the third one-anticipated the Coase Theorem:

1. "[T] $\mathrm{T}$ he fact that economic goods remain where they satisfy the most intensive needs increases the national prosperity or prevents its reduction"31;

2. "[P]rivate law... is built to favor the movement of economic goods wherever those goods have the highest value and utility. In general, the implementation of the rules of private law leads to an increase of national prosperity and to a multiplication of economic goods, transferring objects to those individuals who are able to extract from them a particularly high utility from the standpoint of production or consumption (to the appropriate recipient [podhodjašcij destinatar] $)^{32}$;

3. The larger the legal-political "errors in the assignment of economic goods...the more vigorously psychological forces will oppose [the corresponding] law, and the more important it will be for the parties to ignore it and to arrange things differently by mutual agreement on a voluntary basis" ${ }^{\prime 3}$.

It is worth evaluating Petrazhycki's ideas from the perspective of contemporary consequentialism ${ }^{34}$. Consequentialism holds that practical activities should be evaluated based on the consequences they produce. It came to be applied in legal science: (1) from the standpoint of economics in the analysis of the economic impact of a normative act, and (2) from the standpoint of ecology in the analysis of the impact of a normative act may have on the environment and on technology.

No one disputes the legitimacy of the principle of analyzing the regulatory impact of legislation.

On the other hand, the possibility of using consequentialism in relation to judicial decisions was controversial. In my opinion, if we distinguish different kinds of judicial decisions and focus on "strategic" or "normative" judicial decisions-i.e., the judicial precedents of the supreme and constitutional courts-consequentialism can also be applied to them.

There is an essential difference between the traditional juristic method for evaluating the impact of norms and the economic method. The former adopts a retrospective standpoint, whereas the latter adopts prospective one. Jurists evaluate the impact of norms after a fact (a "case") has taken place. Mathis observes that the focus is on the direct consequences at a

\footnotetext{
30 Posner R. Economic Analysis of Law. 9th ed. New York, 2014. P. 34-35.

31 Petrazhycki L. Theory and Policy of Law...P. 128

32 Idem. Rights of Bona Fide Owner...P. 206

33 Idem. Theory and Policy of Law... P. 148.

${ }^{34}$ Mathis K. Consequentialism in Law. Efficiency, Sustainability, and Justice to Future Generations.
} Dordrecht, 2011. 
micro-level when the consequences of a judicial decision are examined. The macro-level consequences are typically not examined by ordinary judges. The judicial decisions arrived at by the justices of the supreme or constitutional courts are exceptions because those courts are concerned with balancing rights and/or legal interests having the same status by means of the principle of proportionality.

From the standpoint of the economic analysis of law, the focus is on the economic consequences of judicial decisions on a macro-level, that is, at the level of the national economy, and especially on its impact on future behavior. While the criteria of evaluation have a juristic, normative character for a retrospective assessment, it is the efficient allocation of resources that matters for a prospective one.

Nicolas Luhmann holds that it is necessary to relieve the judiciary of the burden of responsibility for the consequences of judicial decisions. He argues that consequentialism may jeopardize the dogmatic or doctrinal independence of the legal system and interfere with the adoption of decisions ${ }^{35}$. In my opinion Luhmann makes the mistake of ignoring the philosophical distinction between the general and the particular. Many decisions adopted by the courts of highest instance can be considered from two different viewpoints depending on whether (1) a case is regarded as something unique or unrepeatable, or (2) it is regarded as a template that can provide guidance when considering analogous cases ${ }^{36}$. A judicial precedent is a particular judicial decision from which it is possible to extract general norms for analogous cases.

In Petrazhycki's writings we can find exceptionally interesting considerations in regard to the discussion opened by Luhmann. I am thinking of Petrazhycki's critique of Jhering's "practical jurisprudence" to be found in his Theory of Incomes, his Trendy Slogans in Jurisprudence, and his Introduction to the Science of Legal Policy. According to Petrazhycki, Jhering and his followers regarded private law as merely a tool used by the courts. They held that for legal practitioners law should be precisely a judicial tool easily amenable to manipulations, and this constitutes the whole of so-called "practical jurisprudence" (praktische Jurisprudenz).

In his critique Petrazhycki offers some general considerations in regard to the way the norms of private law should be evaluated. He argues that

it is necessary to shift the focus to the domain of a different "practicality" [praktika] in light of the fact that the essence of private law does not consist of the "protection" of the interests of the citizens but of the positive organization of a decentralized system for a national economy (or of a decentralized social structure, if we are to speak also of such non-economic matters as marital relations, paternal authority, etc.) and of its positive impact on character and especially on people's ethics ${ }^{37}$.

Thus, if Luhmann sought to defend legal dogma against attempts to "water it down"-and rightly so-Petrazhycki also defended the independence of legal dogma by distinguishing it from legal policy ${ }^{38}$ and also by initiating the evaluation of the norms of private law from a legalpolitical viewpoint. In this connection, it is worth recalling that, when Petrazhycki considered the teaching method proposed by Jhering-a method based on the solution of practical caseshe found Jhering's approach extremely useful for students because it "shows them how abstract

${ }^{35}$ Luhmann N. Rechtsoziologie. Sociological Theory of Law. London, 1985. P.232; Mathis K. Op. cit. P. 8.

${ }^{36}$ More on this can be found in: Weinreb L. Legal Reason: The Use of Analogy in Legal Argument. Cambridge, 2016.

37 Petrazhycki L. Theory and Policy of Law...P. 171.

${ }^{38}$ Fittipaldi E. Nauka na sluzhbe u printcipa zakonnosti: kriticheskaya zaschita kontcepcii juridicheskjoi dogmatyki Lva Petrazhitskogo [Science as Servant of Law: A Critical Defence of Legal Dogma Concept of Lev Petrazhycki // Pravovedenie, 2013, no 5, p. 48-76. 
legal concepts are relevant and have an absolutely real impact on life" ${ }^{39}$. On the other hand, he observes that "such explanations should be...sharply distinguished from the legal-political evaluation of legal norms"

As Petrazhycki writes:

$[B] y$ pointing out what particular and concrete decisions are contained in a given legal concept or a general provision, we are not yet in any way touching a completely different question-let alone solving it. This is the question of whether or not that general provision is rational from the standpoint of legal policy ${ }^{41}$.

$\mathrm{He}^{42}$ explains that it is necessary to assess the rationality of the provisions of private law "from the standpoint of political economy", and he comes to the following conclusion:

In general, the freedom of contract, both from the standpoint of the success a national economy and from a pedagogical one, is a necessary condition for the success and completion of a decentralized [economic] system (the same holds for the freedom to exercise property rights, for the freedom of movement of individuals, to some extent for testamentary freedom, etc.). Further, it should be noted that, in general, a policy aimed at limiting the freedom of the individual, property, or contracts by means of private-law or public-law legislation in the pursuit of so-called social goals, thus leading to a more extensive and intensive state intervention in economic life (for example, the conversion of a certain sector of production, trade, etc., into a state monopoly), is not equally appropriate for every kind of national mentality. If the mass of people has not yet arrived at the stage of the bonus pater familias in sufficient numbers and the state therefore does not have enough suitable personnel at its disposal, then from both an economic viewpoint and from a pedagogical one, [economic] decentralization is useful. For the same reason the private freedom of firms [hozjajstva] is useful, while the expansion of state economy [hozjajstvo] certainly is not ${ }^{43}$.

This piece of advice remains very pertinent for contemporary Russia.

\section{Conclusion}

It is of paramount importance to find precise words to characterize the very evident connection between Petrazhycki's legacy and the economic analysis of law. Perhaps it is an exaggeration to state that he belongs among the founders of this scientific tradition. A more appropriate word might be "forerunner". I argued that contemporary economic analysis of law, or law and economics, may be regarded as the implementation of Petrazhycki's dream of a new science of legal policy. It is unknown to me whether Commons, Calabresi, Posner, and Ulen are acquainted with his works. Most probably they are not, but that is beside the point. What matters is that there is a clearly discernible chain of ideas that becomes apparent if we consider the goals pursued by those scholars. Petrazhycki's teachings on the policy of law and economic analysis of law are links in the unitary intellectual chain of contemporary rational legal science or theory. The first links were already forged in the Middle Ages in the works of philosophers and mathematicians and - much later—in those of jurists. Leibniz, Pufendorf, von Savigny, and Petrazhycki, as well as Commons, Posner, Buchanan, Becker, Coase, and Calabresi have basically set themselves a single goal: to bring a more rational order to conceptions related to law,

\footnotetext{
39 Petrazhycki L. Theory and Policy of Law... P. 159.

40 Ibid.

41 Ibid.

${ }^{42}$ Ibid. P. 166.

43 Ibid.
} 
to create a non-formalistic legal science (as an alternative or as a supplement-in Petrazhycki's case-to legal dogmatics or doctrine), to rid that science of excessive fictions, and-most importantly-to change the cognitive methods for the study of law. Perhaps, a way to connect Petrazhycki and modern economic analysis of law can be found in Michel Foucault's Archeology of Knowledge $e^{44}$. Foucault is well known for advocating an "archeological" or "genealogical" analysis of ideas dealing with a subjectless space and so amounting to a form of history of the formation of scientific knowledge and discourses which does away with the need to invoke the subject.

\section{国 References}

Avenarius M. (2014) Fremde Traditionen des römischen Rechts. Einfluß, Wahrnehmung und Argument des 'rimskoe pravo' im russischen Zarenreich des 19. Jahrhunderts. Göttingen: Wallstein, S. 776.

Becker G. (1991) A Treatise on the Family. Cambridge (Mass.): Harvard University Press, 329 p.

Buchanan J. 2000 [1975]. The Limits of Liberty: Between Anarchy and Leviathan. Indianapolis: Liberty Fund, $261 \mathrm{p}$.

Coase R. (1960) The Problem of Social Cost. Journal of Law and Economics, no. 3, pp. 1-44.

Commons J. (1924) Legal Foundations of Capitalism. N.Y: MacMillan, 394 p.

Dworkin R. (1980) Is Wealth a Value? The Journal of Legal Studies, no 9, pp. 191-226.

Fittipaldi E. (2009) Bonae fidei possessor fructus consumptos suos facti. Tentative Answers to One Question Left Open by Leon Petrazycki's Economic Analysis of Law. Societas/Communitas, no. 7, pp.15-36.

Fittipaldi E. (2013) Nauka na sluzhbe u printsipa zakonnosti: kriticheskaya zashchita kontseptsii yuridicheskoy dogmatiki L'va Petrazhitskogo [Science and Legality Principle: Critical Defence of Concept of Leon Petrazycki Legal Dogma]. Pravovedenie, no. 5, pp. 48-76.

Gadzhiev G.A. (2016) Pravo i ekonomika (metodologiya) [Law and Economics: Methodology]. Moscow: NORMA, 256 p. (in Russian)

G'yaro T. (2009) Leon Petrazhitskiy - osnovopolozhnik ekonomicheskogo analiza prava [Leon Petrazycki, Founder of Economic Analysis of Law] Ekonomika. Predprinimatel'stvo. Okruzhayushchaya sreda, no. 2.

Grechenig K., Gelter M. (2008) The Transatlantic Divergence in Legal Thought: American Law and Economics vs. German Doctrinalism. Hastings International and Comparative Law Review, no. 1, pp. 295-360.

Karapetov A.G. (2016) Ekonomicheskiy analiz prava [The Economic Analysis of Law]. Moscow: Statut, 528 p. (in Russian)

Kolbinger F. (2004) Im Schleppseil Europas? Das russische Seminar für römisches Recht bei der juristischen Fakultät der Universität Berlin in den Jahren 1887-1896. Frankfurt am Main: Klostermann, $251 \mathrm{~S}$.

Mathis K. (2011) Consequentialism in Law. Efficiency, Sustainability, and Justice to Future Generations. Dordrecht: Springer, $240 \mathrm{p}$.

Menger A. (1886) Das Recht auf den vollen Arbeitsertrag in geschichtlicher Darstellung. Stuttgart: Cotta, $171 \mathrm{p}$.

Muromtsev S.A. (1879) Opredelenie i osnovnoe razdelenie prava [Definition and Fundamental Separation of Law]. Moscow: Mamontov, 240 p. (in Russian)

Petrazycki L. (1893-1895) Die Lehre von Einkommen. Vom Standpunkt des gemeine Civilrechts unter Berücksichtigung des Entwurfs eines bürgerlichen Gesetzbuches für der Deutsche Reich. Berlin: Müller.

${ }^{44}$ Foucault M. L'archéologie du savoir. The Archeology of Knowledge and the Discourse on Language. New York, 1972. 